\title{
PERBEDAAN KONSEPSI RECHTSTAAT DAN THE RULE OF LAW SERTA PERKEMBANGAN DAN PENGARUHNYA TERHADAP HUKUM ADMINISTRASI NEGARA
}

\author{
M. Syahnan H., SH., M. Hum ${ }^{1}$
}

\begin{abstract}
Abstrak:
Dua konsepsi negara hukum sama-sama memberikan jaminan dan perlindungan hukum terhadap hak asasi manusia dan sama-sama membatasi tindakan penguasa melalui hukum. Perkembangan dua konsep negara hukum itu tidak hanya berpengaruh terhadap perkembangan hukum pada negara itu, akan tetapi berpengaruh terhadap perkembangan hukum di dunia dan negara-negara bekas jajahannya. Merealisir negara kesejahteraan, manusia tidak hanya semata-mata menjadi manusia teknokrat, Negarawan, Politisi, Manager dan Ilmuwan. Akan tetapi harus menjadi warga yang baik dan berkesusilaan.
\end{abstract}

Kata Kunci : Recht Staat, The Rule Of Law, dan Hukum Administrasi Negara.

${ }^{1}$ Dosen tetap Fakultas Hukum Universitas Suryadarama dan aktif di Lembaga Konsultasi dan Bantuan Hukum (LKBH) Fakultas Hukum Universitas Suryadarama 


\section{PENDAHULUAN}

Dalam membicarakan konsepsi rechtstaat dan dan the rule of law, maka yang terlintas dalam pikiran kita, di dalam negara itu yang mempunyai kekuasaaan tertinggi (sovereign) adalah hukum bukan kekuasaan. Bukan hukum yang tunduk pada kekuasaan tetapi kekuasaanlah yang harus tunduk pada hukum. Ada ramburambu kekuasaan yang batas-batasnya ditentu kan oleh hukum. Ini adalah tugu utama (prinsip) negara hukum.

Konsepsi negara hukum secara tegas terpapar dalam pasal 1 ayat 3 UUD 1945 yang menentukan bahwa Indonesia adalah negara hukum (Morissan, 2005 : 105).

Dari pernyataan itu jelas bahwa ada tuntunan atau pedoman dalam kehidupan bernegara dan berbangsa. Pedoman itu harus dipatuhi secara bersama baik oleh negara maupun rakyat. Sadar akan hak, kewajiban, tugas dan tanggung jawab yang harus dipatuhi oleh warga negara maupun penguasa dari negara yang bersangkutan.

Kemudian dalam negara hukum tidak boleh bersemayam autoritarisme dan totalitarisme. Autoritarisme adalah kehendak untuk memerintah atas kuasa sendiri. Sedangkan totalitarisme adalah kehendak memerintah dengan melakukan pemusatan kekuasaan secara total pada negara (Notohamidjojo, 1967 : 2). Itu adalah kekuasaan yang melarang pertanggung jawaban kepada rakyat atau parlemen. Andaikatapun ada pelanggaran pertanggung jawaban, dilakukan dengan cara yang semu atau pura-pura dan atau dilakukan dengan secara rahasia. Sehingga rakyat takut untuk mengatakan atau menyatakan pikiran dan atau perasaannya baik dengan tulisan atau dengan lisan.

\section{PERUMUSAN MASALAH}

Berangkat dari latar belakang masalah tersebut di atas maka masalah dapat di identifikasi sebagai berikut :

1. Apakah perbedaan pengertian konsepsi rechtstaat dan the rule of law?
2. Bagaimanakah perkembangan dan pengaruh kedua konsepsi dari negara itu terhadap hukum administrasi negara?

\section{PEMBAHASAN}

1. Perkembangan dan Pengaruh Konsepsi. Rechtstaat dan The Rule of Law di Inggris dan Perancis

Seperti kita ketahui, lahirnya konsepsi rechtstaat maupun the rule of law adalah usaha atau menentang tindakan sewenang-wenang dari penguasa. misalnya, di Inggris (1212) adalah untuk menumpas kekuasaan absolut dari Raja John The Lackland. Sedangkan di Perancis adalah untuk menumpas kekuasaan absolut dari Raja Louis XVI (1789).

Kemudian kedua negara itu, mempunyai sistem hukum yang berlain-lainan. Perancis menganut konsepsi rechtstaat sedangkan Inggris menganut konsepsi the rule of law. Dari dua sistem hukum ini dalam perkembangannya tidak hanya berpengaruh terhadap isi dan penegakan hukum di negara yang bersangkutan. Tetapi juga dapat memberi pengaruh bagi negara-negara yang ada di dunia terutama bekas jajahannya.

Konsepsi negara hukum Eropa Kontinental menggolongkan hukum atas Hukum Publik dan Hukum Privat. Sedangkan negara hukum yang menganut konsepsi the rule of law, seperti Inggris, tidak mengenal adanya penggolongan hukum tersebut. Mereka hanya melihat perbuatan benar atau salah. Hal itu dapat diketahui dari hak-hak dan kewajibankewajiban hukum masing-masing (baik itu hubungan warga negara dengan negara, atau hubungan negara dengan warga negara dan atau hubungan sesama warga negara). 
Walaupun kedua negara hukum itu sama-sama memiliki konsepsi yang berlainan, namun pada hakekatnya kedua konsepsi negara hukum itu sama-sama ingin memberikan jaminan dan perlindungan hukum terhadap hak-hak azasi manusia. Juga sama-sama ingin membatasi tindakan penguasa melalui hukum.

Dari bidang peradilan, negara yang memakai konsepsi rechtstaat mengenal adanya dua set pengadilan, yaitu peradilan umum dan peradilan administrasi. Sedangkan Inggris yang menganut konsepsi the rule of law hanya mengenal satu set peradilan yaitu ordinary court (Philip M. Hadjon, 1987 : 5).

Dari uraian tersebut di atas dapat kita ketahui, pada negara yang mengandung konsepsi rechtstaat membedakan pengadilan bagi warga negara yang melakukan kesalahan dan tindakan penyalahgunaan wewenang oleh penguasa (detournement de pouvoir). Pelanggaran hukum oleh sipil diadili oleh peradilan umum sedangkan tindakan penyalahgunaan wewenang diadili oleh peradilan administrasi.

Pada negara yang menganut konsepsi the rule of law, seperti Inggris hanya mengenal satu set peradilan yaitu ordinary court dengan mendasarkan diri pada doktrin ultra vires.

Meskipun Inggris tidak mengenal peradilan administrasi, namun dewasa ini di Inggris telah muncul ber bagai badan khusus yang disebut special tribunals atau administrative tribunals. Untuk menangani kasus-kasus perlindungan hukum bagi rakyat terhadap tindakan sewenang-wenang dari penguasa.

Namun hal yang menarik adalah diterimanya lembaga Onbudsman di Inggris, yaitu dengan terbentuknya parliamantry commissions (act 1967) yang dikatakan sebagai an office that probably has no precise counter part outside the united kingdom.

Mengenai perlindungan hukum di negara Belanda dalam prakteknya dapat ditempuh melalui tiga jalan atau terdapatnya tiga kemungkinan untuk itu.

a. Melalui hakim biasa yang pada umumnya lewat jalur "Kantongenrechten","Arrondissen mentsrechtsbanken","Gerechtshove $n$ " dan "Hoge Raad".

b. Melalui administratif beroef yang bandingnya ditujukan kepada Centrale Raad Van Beroep atau College Vam Beroep.

c. Melalui Hakim Administratif pada "Afdeling rechtspraak Van de Raad Van State" yang merupakan tribunaltribunal administratif.

Sedangkan dalam kerangka mewujudkan negara kesejahteraan umum administrasi negara menjadi sangat penting karena :

a. Sarana-sarana (instrument bagi penguasa untuk mengatur, mengembangkan dan mewujudkan berbagai kepentingan masyarakat).

b. Masalah cara-cara partisipasi warga masyarakat dalam proses termasuk mewujudkan kesejahteraan masyarakat perkembangan hukum bagi warga masyarakat (Riduan HR, 2011 : 45).

Dalam Tabel (SiachranBasah, 1989 : 137)

\begin{tabular}{|c|c|}
\hline \multicolumn{2}{|r|}{ Peradilan } \\
\hline Peradilan Umum & Peradilan Administrasi \\
\hline Hoge Raad & Tribunal-tribunal administratatifpada \\
\hline & $\begin{array}{l}\text { afdeling rechtspriaak van de raad vam } \\
\text { state. }\end{array}$ \\
\hline Gerechtshoven & Centrale raad van beroep. \\
\hline Arrondissenmen .tsrechtbanken & College van beroep. \\
\hline Kantongentrechten & \\
\hline
\end{tabular}


2. Perkembangan Konsepsi Rechtstaat dan The Rule of Law di Indonesia

Pada masa orde lama rechtstaat menjadi mode negara hukum kita. Itu sebagai aplikasi dari penjelasan UUD 1945 tentang penjelasan mengenai sistem pemerintahan negara; Indonesia ialah negara yang berdasarkan atas hukum (rechtstaat), bukan berdasarkan matchstaat (kekuasaan belaka) atau wilkurstaat. Penjelasan pasal 17 dari UUD 1945 juga menyatakan dengan tegas ia bukan diktator; artinya kekuasaan tak terbatas. Tetapi keadaan yang nampak pada waktu itu justru sebaliknya, yaitu kekuasaan merajalela (dilakukan sakersa kersaning dewek), seperti adanya pengangkatan Presiden seumur hidup.

Dengan adanya kekuasaan dari orang yang merajalela pada waktu itu dari orang yang kebetulan sedang berkuasa, menjadi penyebab dikeluarkannya TAP MPRS No. XXXIII/MPRS/I967 tentang pencabutan kekuasaan pemerintahan dari tangan Presiden Soekarno.

Sejak perjuangan orde baru di tanah air kita, mode negara hukum berganti menjadi the rule of law sebagai kontras terhadap the rule of one man, seperti yang dipraktekkan pada masa orde lama yang telah membawa malapetaka pada bangsa kita terutama dalam bidang politik, ekonomi dan moral. Keadaan itu menjadi tantangan bagi kita walaupun bukan perjuangan yang mudah.

Sebagai upaya bangsa kita adalah menegakkan supremasi hukum dengan mewujudkan stabilisasi nasional. Dan hukum harus dipatuhi bukan saja oleh rakyat atau setiap penduduk, melainkan juga harus ditaati oleh setiap aparatur dan pejabat pemerintah. Demikian antara lain ditegaskan oleh Pd. Presiden Soeharto pada waktu upacara pelantikan Prof. Suoekti sebagai Ketua Mahkamah Agung yang baru (Pidato Pd. Presiden Soeharto , 1971 : 16).

Kalau kita perhatikan sebenarnya apa itu rechtstaat maupun the rule of law adalah senapas. Sama-sama ingin menegakkan negara hukum secara temporal (ruang, waktu dan keadaan), ingin menjunjung harkat dan martabat manusia. Bagi penulis sendiri istilah itu tidak penting, yang lebih penting adalah bagaimana cara membentuk negara hukum itu menjadi lebih bermakna. Sehingga welfare state menjadi kenyataan.

3. Pengaruh Perkembangan Konsepsi Rechtstaat dan The Rule of Law terhadap Perkembangan Hukum Administrasi Negara Indonesia

Perkembangan Hukum Administrasi Negara di Indonesia banyak dipengaruhi oleh perkembangan Hukum Administrasi Negara Belanda dan Perancis. Hal itu disebabkan keadaan historis. Di mana kita pernah dijajah oleh Belanda dan Belanda pernah menjadi jajahan Perancis.

Menurut riwayatnya, pada mulanya Hukum Administrasi itu merupakan bagian dari Hukum Tata Negara, tetapi akibat perkembangan masyarakat dan studi ilmu hukum yang memperlihatkan tuntutan akan munculnya kaidah-kaidah hukum baru suatu saat Hukum Administrasi Negara akan bergeser menjadi hukum yang berdiri sendiri.

Berkaitan dengan hal tersebut di atas, dalam usaha untuk mencapai tujuan negara sebagaimana yang termaktub dalam Pembukaan UUD 1945 alinea IV, menegaskan ".............. melindungi segenap bangsa Indonesia dan seluruh tumpah darahIndonesia dan untuk memajukan kesejahteraan umum, mencerdaskan kehidupan 
bangsa, dan ikut serta melaksanakan ketertiban dunia yang berdasarkan kemerdekaan, perdamaian abadi dan keadilan sosial........"

Untuk mencapai tujuan negara itu, maka peranan Hukum Administrasi itu sangat penting untuk mengatur, menyelenggarakan dan pendayagunaan administratif baik itu hal yang bersifat interen maupun yang bersifat eksteren.

Upaya produktif peningkatan dan penyempurnaan bidang-bidang hukum terus dilaksanakan dalam rangka memperkokoh makna daripada negara hukum, yaitu hal yang mengatur hubungan-hubungan antara warga negara dengan pemerintah, hubungan itu akan tampak warnanya dalam menjalankan tugas-tugas pemerintahan, yang sering disebut "Public Service".

Mengenai eksistensi peradilan tata usaha negara (administratif) di samping peradilan umum, yang agak divergerend dengan negara-negara yang mengikuti "Civil Law System". Hampir dapat dikatakan, bahwa mengenai hal ini di Indonesia menempati posisi tengah-tengah "Intermediate" antara negara yang menganut sistem civil law dan negara yang menganut konsepsi the rule of law. Bila ditegaskan lagi kita menganut aliran jalan tengah.

Perancis dengan Conseil d'Etatnye (dengan bagian de Contentieuse, khususnya untuk peradilan administrasi), yang berdampingan dengan Cour de Cassation sebagai puncak dari peradilan umum, Jerman Barat dengan"Verwaltungsgerichtskof" (puncak peradilan adrainistratif) hidup berdampingan dengan "Bendes Gerichshol" yang mengadili perkara perdata dan pidana dan selaku demikian adalah puncaknya dari peradilan umum, sedangkan Conseil
d'Etat dan Verwaltungsgerichtskop tersebut adalah puncak tersendiri dari peradilan administratif (Afdeling Rechtspraak) (Baharuddin Lopa, 1991 :85).

Di Indonesia Mahkamah Agung merupakan puncak tunggal dari kedua .lingkungan peradilan-peradilan umum dan peradilan tata usaha negara (administratif). Indonesia lebih mendekati sistem Perancis dengan adanya lingkungan peradilan administrasi dan umum.

Dalam kaitan bidang pengadilan, juga perkembangan hukum administrasi, negara itu merupakan amanat dari pasal 10 dari UU No. 14 tahun 1970. Pasal 10 dari UU No. 14 tahun 1970 menegaskan bahwa kekuasaan kehakiman dilakukan oleh pengadilan dalam lingkungan :

a. Peradilan umum.

b. Peradilan agama.

c. Peradilan militer.

d. Peradilan tata usaha negara.

Kemudian dalam TAP MPR No. IV/MPR/1978, mengenai GBHN dalam Bab 4 tentang pola umum Pelita ke III di bidang politik, aparatur pemerintah, hukum, penerangan dan pers, hubungan luar negeri, sektor hukum butir D menyebutkan bahwa : akan mengusahakan peradilan Tata Usaha Negara.

Usaha pemerintah dan DPR untuk merealisir dari amanat dari UU noir.or 14 tahun 1970 dan GBHN itu baru terwujud dengan lahirnya UU nomor 5 tahun 1986, yaitu tentang peradilan Tata Usaha Negara (Padmo Wahyono, $1982: 124)$.

Dengan lahirnya UU nomor 5 tahun 1986 itu pemerintah menyiapkan calon-calon hakim dan tenaga staf kepaniteraan dari berbagai pengadilan negeri dan pegawai tinggi di seluruh 
Indonesia yang biasa menyelesaikan perbuatan melawan hukum oleh penguasa (onrechtmatige overheidsdaadzaken) atau disebut dalam buku Perancis detournement de vouvoir.

Untuk merealisir UU nomor 5 tahun 1986 itu pe-merintah, menyelenggarakan penataranpenataran yang dilakukan oleh Mahkamah Agung dengan Departemen Kehakiman dan berjalan sampai 3 angkatan dan berakhir tang gal 3 Agustus 1990 dan penataran lanjutan khusus bagi staf peratun pada bulan Oktober 1990. Kemudian diselenggarakan lagi penataran Pusdiklat di Cinere selama waktu satu bulan. Kemudian para calon hakim Tata Usaha Negara dikirim ke Perancis untuk keperluan pengisian tenaga peratun itu (Indroharto, 1991 : 23)

Dari uraian tersebut di atas nampak bahwa bidang peradilan kita juga mengikuti jejak sistem hukum yang berlaku di Eropa Kontinental, yaitu konsepsi hukum rechtstaat. Di mana dipisahkan perbuatan melawan hukum oleh sipil dan perbuatan hukum oleh penguasa (abuse of law). Hal itu dilakukan dalam rangka mengupayakan negara kesejahteraan umum (welfare state) sebagai kewajiban pemerintah dalam mewujudkan pemerintahan yang baik atau layak (besstuurzorg).

Dengan peratun diharapkan segala tindakan pemerintah dapat dilaksanakan menurut hukum, baik in apperiance maupun in reality.

\section{KESIMPULAN}

Dari hasil pembahasan di atas maka kesimpulan adalah sebagai berikut :

1. Lahirnya konsepsi negara hukum baik itu rechtstaat maupun the rule of law adalah untuk menumpas kekuasaan raja yang bersifat absolut, yaitu di
Perancis Raja Louis XVI dan di Inggris Raja John The Lack.

2. Perkembangan negara hukum mulai dari negara hukum formil (nachwakerstaat) menuju ke arah hukum materil (welvaarstaat). Hukum tidak hanya mempertahankan dan melindungi rakyat tetapi hukum harus dapat mengarahkan masyarakat ke arah kese'jahteraan.

3. Negara hukum Eropa Kontinental mengutamakan hukum ter-tulis daripada yurisprudensi, sedangkan Inggris mengu-tamakan yurisprudensi daripada hukum tertulis.

4. Perkembangan hukum di negara yang menganut konsepsi rechtstaat berkembang secara revolusioner sedangkan negara hukum yang menganut konsepsi hukum the rule of law berkembang secara evolusioner.

5. Baik itu konsepsi rechtstaat maupun the rule of law adalah senapas. Samasama ingin mengarah ke masyarakat ke arah kesejahteraan.

6. Negara Republik Indonesia menganut konsepsi rechtstaat. Sebagai bukti adanya aturan penjelasan dan adanya per-adilan untuk sipil dan penguasa yang menyalahkan wewenang.

7. Negara Republik Indonesia baru berangkat dari negara hukum formal ke negara hukum materil. Masih dalam perjalanan.

8. Konsepsi hukum rechtstaat mengenal dua set peradilan yaitu peradilan umum dan administrasi, sedangkan konsepsi the rule of law hanya mengenal satu set peradilan, yaitu yang ditangani oleh ordinary court berdasarkan ultra vires.

9. Indonesia baru mengenal dua set peradilan setelah UU nomor 5 tahun 1986.

10. Dalam perkembangan negara hukum Indonesia menganut aliran jalan tengah "Intermediate" antara yang menganut konsepsi rechtstaat dan the rule of law. Sebab di samping itu kita mengakui sistem hukum terkodifikasi, kita juga memakai hukum yurisprudensi. 


\section{DAFTAR PUSTAKA}

Abu Daud Busroh, Dkk. , Az.as-azas Hukum Tata Negara Penerbit Ghalia, 1983.

Baharuddin Lopa, Mengenal Peradilan Tata Usaha Negara. Penerbit Sinar Grafika, 1991,

Djoko Prakoso dk, Euthanasiat Hak-hak Azasi Manusia dan Hukum Pidana. Penerbit Ghalia Indonesia, 1984.

E. Utrecht/Moch. Saleh Djindang, Pengantar Hukum Administrasi Negara. Penerbit PT. Ichtiar Baru, 1990.

Indroharto, Usaha Memahami UU Tentang Peradilan Tata Usaha Negara. Penerbit Pustaka Sinar Harapan, 1991.

Morissan, Hukum Tata Negara RI era Reformasi, Randina Prakasa, 2005

Notohamidjo jo, Makna Negara HukumT Badan Penerbit Kristen-Djakarta, 1967.

Padmo Wahyono, Indonesia Berdasarkan Atas Hukum Penerbit Ghalia Indonesia, 1982.

Philipus M. Hadjon, Perlindungan Hukum Bagi rakyat. PT. Bina Ilmu, 1987.

Siachran Basah. Eksistensi dan Tolok Ukur Badan Peradilan Administrasi di Indonesia. 1989

ST. Marbun, DK. , Pokok-pokok Hukum Administrasi Negara, Penerbit Liberty Yogyakarta, 1987

Sudjono, Pengantar Ilmu HukumT Penerbit Alumni Bandung, 1986.

Sunaryati Hartono, Apakah The Rule of Law itu. Penerbit Alumni Bandung, 1982.

Ridwan HR, Hukum Administrasi Negara, Grafindo Persada, 2011. 